\title{
20. Norvégia, \\ a kivételes intézkedések országa
}

\author{
CSEMÁNÉ VÁRADI ERIKA
}

\section{A különleges jogrend alkotmányos és törvényi szintü szabályozása}

Norvégia - államberendezkedéséből adódóan - számtalan, a magyartól eltérő múködési mechanizmust és szabályozási megoldást alkalmaz. Ugyanakkor - bár nem tagja az Európai Uniónak - sok hasonlóság is megfigyelhető más EU-s tagországgal, így elsősorban Svédországgal, illetve Dániával. Ennek hátterében a három ország történelmében 1029-tôl végig jelen lévő közös királyságok, ${ }^{1}$ uniók, illetve (elsősorban a svédek ellen vívott) háborúk állnak. A II. világháború után megindult skandinavista egyesülési folyamat keretében pedig más

1 1029-ben volt először közös királya Dániának és Norvégiának, 1397-től pedig Kalmári Unióként Svédországgal együtt közös uralkodó irányította a birodalmat. Svédország 1523-as kilépése után 300 évig a dán-norvég perszonálunió tovább élt, bár Norvégia 1536-tól már csak mint dán tartomány jelent meg (és nem önálló királyság). A svédekkel folytatott folyamatos háborúzás után 1814-től az ország Svédország birtokába került. 1905. június 7-én a norvég parlament egyhangúlag mondta ki az unió felbontását. Ezt követően egészen napjainkig a dán király, illetve a királyi család leszármazottjai birtokolják a norvég trónt (Universitetet i Oslo, 2020).

Csemáné Dr. Váradi Erika, PhD, LLM

judit.erika.varadi.csemane@mfi.gov.hu vezető kutató (Mádl Ferenc Összehasonlító Jogi Intézet)

egyetemi docens (Miskolci Egyetem Állam- és Jogtudományi Kar, Bűnügyi Tudományok Intézete)

Csemáné Váradi, E. (2021) 'Norvégia, a kivételes intézkedések országa' in Nagy, Z., Horváth, A. (szerk.) A különleges jogrend és nemzeti szabályozási modelljei, 434-456. o. Budapest: Mádl Ferenc Összehasonlító Jogi Intézet.

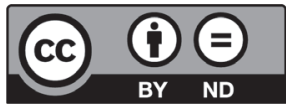


formában ugyan, de tovább folytatódott az együttmúködés. ${ }^{2}$ Így például a hidegháború sújtotta nemzetközi légkör ellenére már 1952-ben létrejött a mindhárom országot érintő Északi Tanács és az Északi Útlevélunió. Ez a szoros történelmi „együttjárás” számos közös müködési jellemzôt eredményez; ilyen például a bíróságok különösen erős szerepe. Mindhárom ország az alkotmánybíráskodás amerikai modelljét követi - azaz nincs szervezetileg elkülönült alkotmánybíróság, alkotmányjogi vita esetén a legfelsőbb bíróság dönt. ${ }^{3}$

Norvégia mint parlamentáris, demokratikus és egységes alkotmányos monarchia élén is a király áll, akinek - bár hatalma szúkült az elmúlt időszakban - szerepe ma sem szimbolikus; aktív résztvevője az ország politikai életének. Széles körü kinevezési jogkörrel rendelkezik, viszonylag erős vétójoggal bír a törvényhozással szemben, emellett a hadsereg fóparancsnoka. ${ }^{4} \mathrm{~A}$ törvények keretei között rendeleteket is alkothat. Elvileg a végrehajtó hatalom letéteményese, hatásköre azonban jórészt ellenjegyzési jog formájában testesül meg. A valódi döntések többnyire a kormányként múködő Államtanácsban születnek. A végrehajtó hatalmat elsősorban gyakorló szervet a miniszterelnök vezeti, tagjai kinevezéséről és felmentéséről az uralkodó dönt, munkájáról a parlamentnek és az uralkodónak egyaránt felelősséggel tartozik.

A különleges jogrenddel összefüggésben az alkotmány mellett egyéb (jog)források is - így különösen a vészhelyzeti felkészültségi törvény ${ }^{5}$ - relevanciával bírnak.

A norvég alkotmány 1814-ben született, és azóta - természetesen módosításokkal, de folyamatosan hatályban van; ezzel Európa legrégebbi ilyen dokumentuma. Mindez jelzi, hogy Norvégia az elmúlt évszázadokban nem állt a történelem viharainak olyan kereszttüzében, mint sok más - főként közép- - európai ország. Másrészt a norvég alkotmány ${ }^{6}$ elsősorban a főbb elveket és kereteket határozza meg, és nem tartalmaz - például a különleges jogrenddel kapcsolatban - olyan részletszabályokat, mint a magyar. A dán nyelven íródott alaptörvény ma is dán nyelvú, a hivatalos szöveg jórészt a nyelv 19. század elején használt formájában érhetô el. Bár az újabb módosításokkal - minden ellenkező törekvés dacára a modern norvég nyelv is bekerült a szövegbe, az egységes nyelvezetú alkotmányszöveg kialakítása évtizedek óta a norvég alkotmányjogi viták kulcskérdése. ${ }^{7}$

Az alkotmány 26.cikke rögzíti, hogy a királynak joga van csapatokat összehívni, háborút indítani a birodalom (az ország) védelme érdekében, békét, szerződéseket (nemzetközi jogi

2 A három ország speciális viszonyára utal a mondás, miszerint Észak-Európában minden újdonság útja az, hogy „a norvég kitalálja, a svéd megcsinálja, a dán nagy haszonnal eladja” (Idézi: Gergely, 1994).

3 Szentgáli-Tóth, 2014. A norvég alkotmányról lásd még: Justis- og beredskapsdepartementet, 2014.

4 Szentgáli-Tóth, 2014.

5 Törvény a háború, a háborús veszély és más hasonló körülmények alatti különleges intézkedésekről (Lov om særlige rådgjerder under krig, krigsfare og liknende forhold [beredskapsloven]; No: LOV-1950-12-15-7) (a továbbiakban: Vészhelyzeti felkészültségi tv.).

6 A Norvég Királyság alkotmánya (Kongeriket Norges Grunnlov).

7 Szentgáli-Tóth, 2014. 
megállapodásokat) kötni és utóbbiakat felmondani, diplomáciai megbízottakat küldeni és fogadni.

A különös jelentőséggel bíró kérdésekről szóló szerződések és - minden esetben - azok a szerződések, amelyek végrehajtása az alkotmány szerint új törvény alkotását vagy az egykamarás parlament (Storting) határozatát teszi szükségessé, addig nem kötelezőek, amíg a parlament azokhoz beleegyezését nem adja, ugyanis a parlament feladata a törvények elfogadása és hatályon kívül helyezése. ${ }^{8}$

Amennyiben a jogalkotási folyamatban a király akadályozott, úgy a távolléte alatt hozott döntéseket a király nevében kell elkészíteni, és azokat az Államtanács írja alá. ${ }^{9}$ Egyes nevesített esetektől eltekintve ${ }^{10}$ a király hiányában a birodalmat az Államtanács irányítja. ${ }^{11}$

A különleges jogrendi szabályozás alapja, hogy minden, a speciális helyzetekből - így a háborúból, szükségállapotból stb. - adódó korlátozásnak összhangban kell lennie a jogszabályokkal.

A skandináv államok újkori történelmét végigkísérte az emberi jogok ${ }^{12}$ kiemelt fontossága, az ott lezajló változásokra, trendekre való fokozott érzékenység. ${ }^{13}$ Így nemcsak a norvég, de az összes skandináv alkotmány által deklarált jogállamiság elvéből következik, ${ }^{14}$ hogy az emberi jogok korlátozása mindig a nemzeti parlament által elfogadott törvény alapján lehetséges. Ez a követelmény - nemzetközi dokumentumokra alapítottan - a norvég jogtudomány szerint ${ }^{15}$ is olyan jogállamisági kritériumokat foglal magában az emberi jogi korlátozásokat tartalmazó jogalkotási aktusok vonatkozásában, mint például

- a transzparencia, a világos, pontos és érthető megfogalmazás követelménye;

- a legitim cél követelménye (a korlátozás megfelel az olyan általános érdekú céloknak, mint a biztonság és/vagy mások jogainak és szabadságainak védelme);

- a szükségesség és az arányosság követelménye;

- a jogok lényegi (immanens) részének sérthetetlensége (korlátozhatatlansága).

Kiemelendő, hogy egy elvi és elméleti szintú, egységes kritériumrendszer - illetve ezekre való hivatkozás - nem jelenik meg írott, tételes formában a norvég alkotmányban. Ez azonban nem egyedi, hasonló megállapítások tehetôk más skandináv alkotmányokat érintően is. Így míg például a Svédországban a kormányzatról szóló alaptörvény 20-25. cikke meglehetôsen részletesen meghatározza az alkotmány által garantált jogok és szabadságok

8 Alkotmány 75. cikk a) pont.

9 Alkotmány 32. cikk.

10 Alkotmány 39-41. cikk.

11 Külön rendelkezés vonatkozik azonban arra, ha az akadályoztatás állandó jellegú, például a király halála vagy tartós betegsége okán.

12 Alkotmány 92-113. cikk.

13 Vik et al., 2018, 190. o.

14 Ojanen, 2018, 146. o.

15 Smet, 2010, 184. o. 
korlátozásának különféle feltételeit, addig a finn alkotmány nem rögzít általános záradékot az emberi jogok megengedett korlátozásáról, noha számos olyan rendelkezést tartalmaz, amelyek különféle módon határozzák meg ezen jogok korlátozásának lehetőségét.

A norvég alkotmány speciális körülményekre alig utal. A norvég Államtanács tagja a miniszterelnök és még legalább 7 személy, akik között a feladatokat a király osztja meg. ${ }^{16}$ Rendkívüli körülmények között a király más norvég állampolgárt is felkérhet a kabinetben való közremúködésre, függetlenül attól, hogy nem tagja a parlamentnek.

Hogy mit jelenthet a rendkívüli körülmény, arra az alkotmány 68. cikkében található példa. A parlament rendszerint minden év októberének első hétköznapján ül össze a birodalom fővárosában, kivéve, ha a király rendkívüli körülmények, például ellenséges invázió vagy fertőző betegség miatt egy másik várost jelöl ki erre a célra. Egyetlen kritérium, hogy egy ilyen döntést kellő időben nyilvánosan közzé kell tenni.

A norvég alkotmány nem ismeri a rendkívüli állapot fogalmát, s nincs speciális, vészhelyzeti alkotmány sem. Norvégia tehát azon államok közé tartozik - Ausztriához, Dániához vagy épp Finnországhoz hasonlóan -, amelyek alkotmányai gyakorlatilag „hallgatnak” a kérdésről ${ }^{17}$ Fontos azonban kiemelni, hogy noha az alkotmány nemcsak a rendkívüli állapot, de - a 68. cikkében található példáktól eltekintve - más, a különleges jogrendet megalapozó körülmény létét sem nevesíti, a gyakorlatban ismert és elfogadott az úgynevezett „alkotmányos szükségesség"18 íratlan szabálya.

Norvégia hosszú idő óta nem állt háborúban más nemzettel. Az ország a II. világháború hadmüveleteiben sem vett részt, azonban ellenállási mozgalmat folytatott a Német Birodalom ellen, amely 1940. április 9-én, a Weserübung hadmúvelettel lerohanta azt. A kezdeti harcok és Haakon király megadást megtagadó nyilatkozatai után az ország végül június 10-én kapitulált, az uralkodó család és a kormány Nagy-Britanniába menekült. ${ }^{19}$ Bár a fegyverszünet megköttetett, a parlament - az „alkotmányos szükségesség” elvére hivatkozva átruházta hatalmát a számúzetésben lévő kormányra.

$\mathrm{Az}$ „alkotmányos szükségesség” tézisét ma is ismeri a norvég alkotmányjog-elmélet, azonban - íratlan szabály lévén - annak pontos hatálya és korlátai nem kimunkáltak és egyértelműek. Alkalmazhatóságának nem vitatott előfeltétele a súlyos vészhelyzet mint szükségességi követelmény, elvei a célorientált arányosság, szükségesség és indokoltság.

16 Alkotmány 12. cikk.

17 Az eltérő szabályozási gyakorlat jól szimbolizálja az uniós tagállamok között e tekintetben fennálló elméleti törésvonalakat. Az országok egy része ugyanis Carl Schmitt nyomán úgy véli, hogy a vészhelyzeteket csak az alkotmányon kívül lehet kezelni, míg mások épp annak fontosságát hangsúlyozzák, hogy ez az alkotmány által a leginkább körülhatárolt és korlátozott kérdéskör kell legyen (Khakee, 2009, 18. o.).

18 Lásd a Velencei Bizottság Norvégiáról szóló országjelentését: „...there is an unwritten but long-established rule that derogations can be made according to an unwritten rule of constitutional necessity". Elérhetó: www.venice.coe.int/files/EmergencyPowersObservatory/NOR-E.htm (Letöltve: 2020. november 11.).

19 Múlt-Kor, 2018. 
A norvég alkotmány a különleges jogrendet megalapozó esetköröket érintően elvétve tartalmaz rendelkezést, hatályban van azonban több olyan konkrét törvény, amely lehetôséget biztosít a veszélyhelyzetek kezelésére. Ilyen például a fertőzéskontrollról szóló törvény, ${ }^{20}$ az egészségügyi felkészültségi törvény, ${ }^{21}$ az ipari felkészültségi törvény ${ }^{22}$ és a polgári védelmi törvény, ${ }^{23}$ míg más jogszabályok egyes szakaszai foglalkoznak veszélyhelyzeti eljárási rendekkel. Utóbbira példa a sugárvédelmi törvény, amely részben rendelkezik a munkavállalók egészségvédelmének biztosítása érdekében a szervezetek oktatási-képzési kötelezettségeiről (például: oktatás, tájékoztatás, írásos utasítás, munkamódszer kidolgozása), ${ }^{24}$ másrészt a rendkívüli események kapcsán követendő lépésekről. Eszerint a társaság köteles készenléti tervet készíteni és a releváns intézkedéseket végrehajtani a balesetek és rendkívüli események kezelésére való képességének fenntartása érdekében. ${ }^{25} \mathrm{~A}$ készenléti tervnek kockázatértékelésen kell alapulnia, és tartalmaznia kell - többek között - az értesítési rutinokat, a készenléti események megszervezését, a felelősségmegosztást, az előre megtervezett protokollokat a különböző helyzetek kezelésére, az esemény mértékének feltérképezésére, a kommunikációra, így az érintett személyzet, a hatóságok és a lakosság tájékoztatására.

Külön is kiemelkedő szerephez jut az 1950-ben elfogadott, de azóta többször módosított Vészhelyzeti felkészültségi tv. A háború, háborús veszély, illetve hasonló körülmények mentén történő mưködésrôl is rendelkező törvény a királynak speciális felhatalmazást ad azokra az esetekre, amikor a parlament az említett körülmények, így a háború miatt nem tudja folytatni tevékenységét. Azaz szabályokat tartalmaz a döntéshozatal és a hatalommegosztás menetére súlyos válságok esetén, beleértve a katonai és a polgári hatalom közötti kapcsolatot (III. fejezet) vagy a büntetöügyek kezelésére vonatkozó különös szabályokat (IV. fejezet).

20 Törvény a fertőző betegségek elleni védelemről (a továbbiakban: Fertőzéskontroll tv.) (Lov om vern mot smittsomme sykdommer [smittevernloven]; No: LOV-1994-08-05-55).

21 Törvény az egészségügyi és szociális biztonságról (a továbbiakban: Eü. felkészültségi tv.) (Lov om helsemessig og sosial beredskap [helseberedskapsloven]; No: LOV-2000-06-23-56).

22 Ipari felkészültségi törvény (Lov om næringsberedskap [næringsberedskapsloven]; No: LOV-2011-12-16-65).

23 Törvény az önkormányzati készenlétről, a polgári védelmi intézkedésekről és a polgári védelemről (a továbbiakban: Polgári védelmi törvény) (Lov om kommunal beredskapsplikt, sivile beskyttelsestiltak og Sivilforsvaret [sivilbeskyttelsesloven]; No: LOV-2010-06-25-45).

24 2000. évi törvény a sugárvédelemról és a sugárzás felhasználásáról (a továbbiakban: Sugárvédelmi tv.) (2000-loven om strålevern og bruk av stråling [LOV-2000-05-12-36]) 7. \$, valamint a sugárvédelemról és a sugárzás felhasználásáról szóló rendelet (a továbbiakban: Sugárvédelmi szabályzat) (Forskrift om strålevern og bruk av stråling [FOR-2016-12-16-1659]) 16. \$.

25 Sugárvédelmi tv. 8. \$, Sugárvédelmi szabályzat 19-20. \$. 


\section{Az alapjogok korlátozására vonatkozó szabályok különleges jogrend idején}

A különleges jogrend eseteit a norvég alkotmány - a hazaihoz hasonló formában - nem határozza meg. A háborús helyzetre is mindösszesen egyetlen, a már idézett 26. cikkében utal.

Az alkotmány nevesíti azokat a jogszabályokat, illetve egyéb jogi dokumentumokat, amelyek nem mellőzhetik a parlament hozzájárulását, illetve a parlament és a király, valamint az Államtanács múködési kereteit. Ezekhez képest a Vészhelyzeti felkészültségi tv. jelentősen eltérő, számos alapjogot korlátozó szabályt határoz meg.

$\mathrm{Az}$ alkotmány szerint a különösen fontos kérdésekkel kapcsolatos szerződések ${ }^{26} \mathrm{csak}^{2}$ akkor válnak kötelezővé, ha ahhoz a parlament hozzájárulását adta. A parlament általános szabályok szerinti múködését akként rendezi az alkotmány, ${ }^{27}$ hogy megalakulását követően a király - vagy az általa erre a célra kinevezett személy - beszédével nyitja meg a parlament eljárását, amelyben tájékoztat a birodalom helyzetéről és azokról a kérdésekről, amelyekre különösen fel kívánja hívni a parlament figyelmét. Egyebekben a király jelenlétében semmilyen tárgyalás nem lehetséges. A parlament ülésének megkezdésekor a miniszterelnöknek és az Államtanács tagjainak azonban joguk van jelen lenni és - mint annak szavazati jog nélküli tagjai - részt venni minden nyílt ülésen. A parlament zárt ülése esetén a tárgyalandó kérdésekbe csak annak engedélyével, az általa megengedett mértékben kapcsolódhatnak bele. A parlament csak akkor tarthat ülést, ha a tagok legalább fele - alkotmánymódosítás esetén legalább a kétharmada - jelen van. ${ }^{28} \mathrm{~A}$ parlament által elfogadott jogszabályok csak abban az esetben válhatnak Norvégia törvényévé, ha ahhoz az uralkodó áldását adja. Az alkotmány szerin ${ }^{29}$ ugyanis ha a király hozzájárul a törvényjavaslathoz, akkor aláírásával látja el, amellyel ez törvénnyé válik. Arra az esetre is tartalmaz rendelkezéseket az alkotmány, ha a király megtagadná hozzájárulását a parlament által elfogadott törvényjavaslatok bármelyikétől - bár erre a Norvégia és Svédország közötti unió 1905-ös felbomlása óta nem volt példa.

Ezzel szemben a Vészhelyzeti felkészültségi tv. előirja, hogy ha a parlament a háború miatt nem tud megfelelően múködni, akkor a király (gyakorlatban a kormány) jogosult minden olyan döntést meghozni, amely az ország érdekeinek védelme (illetve a békés körülményekre való átmenetre felkészülés) érdekében szükséges. Feltétel, hogy ezekről a döntésekről a parlamentet a lehető leghamarabb értesíteni kell. Amennyiben ezen rendelkezéseket a parlament - vagy a király maga - korábban nem vonja vissza, akkor azok legkésőbb az első, a kérdést tárgyaló parlamenti ülés lezárását követően hatályon kívül helyeződnek.30

26 Ugyanez vonatkozik minden olyan szerződésre, amelyet az alkotmány szerint nem lehet új törvény vagy új parlamenti határozat nélkül végrehajtani.

27 Alkotmány 74. cikk.

28 Alkotmány 73. cikk.

29 Alkotmány 78. cikk.

30 Vészhelyzeti felkészültségi tv. 1-2. \$. 
A király speciális felhatalmazással bír, hogy háborúban, a háború közvetlen veszélye, illetve az ország biztonságát vagy szuverenitását fenyegető más veszélyek fennállása esetén törvényi erôvel bíró rendeleteket adjon ki, többek között az ország biztonsága, a közrend, a közegészség, valamint az alapvető javak biztosítása, a katonai, polgári és vagyonvédelmi intézkedések elősegítése és biztosítása érdekében. De mentesíthet a munkavégzés alól, ha azt katonai vagy polgári célok szükségessé teszik. Fontos felhatalmazási elem, hogy az így hozott rendelkezései eltérhetnek az irányadó jogtól is.

Jogbiztonsági célokat szolgál, hogy e döntésekről a lehető leghamarabb szükséges a parlamentet értesíteni és azt azonnal összehívni. Az így hozott döntéseket mind a király, mind a parlament hatályon kívül helyezheti. A parlament határozhat ezek érdemben történő fenntartásáról is; ez esetben a megfelelő eljárás keretében kell őket törvénybe iktatni. ${ }^{31}$

A Vészhelyzeti felkészültségi tv. tartalmaz rendelkezéseket az országnak a kormány ellenőrzése alól háború vagy más súlyos válság miatt kivont területeire, valamint a háború tényleges helyszíneire. Ez esetben a király felhatalmazhatja a megye kormányzóját vagy más helyi hatóságot - ideértve a katonai hatóságokat is - a rendelkezések megtételére. ${ }^{32} \mathrm{Ha}$ nélkülözhetetlen a társadalmilag fontos érdekek védelme, akkor a megyei kormányzó ezen jogokat úgy is gyakorolhatja, hogy az erre vonatkozó felhatalmazás a királytól még nem áll rendelkezésére. ${ }^{33}$

A király dönthet a rendőrség, az egyes rendőri erők vagy az egyes kerületi kapitányságok állományának katonai erőbe történő bevonásáról is. ${ }^{34}$

Az említett vészhelyzetben a büntetőtörvények is megváltozhatnak, ${ }^{35}$ amikor az ország biztonsága vagy szuverenitása veszélyben van. Ezek a rendelkezések komoly jogkorlátozó jelleggel bírnak, s számtalan büntetőeljárás-jogi garanciális alapelv átlépését teszik lehetővé. Így például a gyanú alapjául szolgáló bûncselekmény törvényi büntetési tételeinek nagyságától függetlenül foganatosítható a letartóztatás, eltérő határidők mentén (8. \$). Ezen túl is: a 9 . $\$$ szerint ha a késedelem veszéllyel járna, a vádemelés kérdésében semmiképpen sem kell megkeresni a legfőbb ügyészt. Hasonló feltételek mellett a rendőrfőkapitány gyakorolhatja (a büntetőeljárás-jogi törvény szerint) az államügyészt megillető vádlói hatalmat, míg helyettese (felügyelő) ${ }^{36}$ pedig a rendőrfőkkapitányt megillető végrehajtói hatalmat. A további különös rendelkezések is az eljárás gyorsítását, illetve egyszerúsítését célozzák, a veszélyhelyzetre tekintettel. Ez érinti többek között az egyes bíróságok hatáskörét és illetékességét (10. \$), ${ }^{37}$ a fellebbezéshez való jogot és annak kereteit, illetve jogi relevanciáját (13-14. \$). Feltétel, hogy a háború, háborúval való fenyegetettség vagy a királyság függetlenségének, il-

31 Vészhelyzeti felkészültségi tv. 3. \$.

32 Vészhelyzeti felkészültségi tv. 5. \$.

33 Vészhelyzeti felkészültségi tv. 5. \$.

34 Vészhelyzeti felkészültségi tv. 6. \$.

35 Vészhelyzeti felkészültségi tv. 7-14.\$.

36 A törvény norvég, svéd, illetve angol nyelvú változata eltérő terminológiát alkalmaz.

37 Így a fellebbviteli bíróság helyett a kerületi bíróság járhat el az ügyekben. 
letve biztonságának veszélye miatt a jogorvoslat, illetve a fellebbviteli tárgyalás aránytalan és káros késlekedéshez vezessen.

Néhány kérdésre, így például a demokratikus rend fennmaradásának védelmére szolgáló különös rendelkezésekre nem tartalmaz iránymutatást a jogszabály.

Fontos, a jogelméletben fellelhetô tétel a szükségszerűség doktrínája. ${ }^{38}$ Eszerint „a vészhelyzetek legitimálják az olyan tevékenységet, amely normál körülmények között az alkotmány megsértését vonná maga után". ${ }^{39}$ Súlyos válság esetén ezen elv mentén - amely a norvég történelmi tapasztalatokban gyökerezik - akár az alkotmánnyal ellentétes döntések is születhetnek. Fontos feltétel a súlyos vészhelyzet, valamint az, hogy a szokásos szabályok betartása sem elegendő a nemzeti érdekek védelmében. Ez a parlament hatalmának csökkentésével vagy megszüntetésével jár(hat).

Bár a rendkívüli felhatalmazás esetköreire a korábban jelzettek szerint elsősorban a különböző ágazati jogszabályokban találhatunk példát, Norvégia napjainkra nemzetközi vonatkozásokban is kiemelkedő gyakorlatot alakított ki a vészhelyzetek megelőzése, illetve kezelése vonatkozásában. ${ }^{40} \mathrm{E}$ komplex intézményrendszer, feladatmegosztás és protokoll tekintetében három kérdéskört érdemes kiemelni: a Vészhelyzeti Felkészültségi Bizottság müködését, a katasztrófavédelem felépítését és a kockázatelemzési eljárást.

A kormány vagy egy minisztérium bizottságokat és munkacsoportokat hozhat létre, amelyek a társadalom számára különböző szempontok mentén meghatározó, azokat érintő kérdésekkel foglalkoznak. Tevékenységük eredményét vagy mindenki számára elérhető nyilatkozatokban, vagy jelentés formájában készítik el. A Norvég Nyilvános Vizsgálatok (Noregs Offentlege Utgreiingar, röviden NOU) keretében évente több, az állam múködésének legszélesebb területét lefedő eljárás ${ }^{41}$ zajlik, többek között a családon belüli erőszaktól a jövő kompetenciáin át a városi életfeltételekig, amelyek megállapításait publikálják. E sorozat részeként jelent meg a Når krisen inntreffe (Amikor a válság bekövetkezik) címú jelentés, amelyet 2019. június 14-én nyújtott be ${ }^{42}$ a Vészhelyzeti Felkészültségi Bizottság. A szervezet 2018. február 9-én királyi rendelettel azzal a céllal jött létre, hogy áttekintse a vészhelyzetekre való felkészülésről szóló jogszabályokat, s készítse elő a szükséges módosító javaslatokat.

A krízisszabályozásról szóló III. fejezet bevezetője ${ }^{43}$ (7.1.) utalt arra, hogy Norvégiában aktuálisan számos ágazati törvény létezik, amelyek az egyes ágazatok számára különféle vészhelyzeti felkészülési rendszereket tartalmaznak, például válságok vagy katasztrófák esetére. De külön ágazati szintű törvények szólnak többek között a polgári védelemről. A jelentés részben azt vizsgálta, hogy milyen gátló tényezők áll(hat)nak fenn a jelenlegi rendelke-

38 Lásd erről részletesebben: Andenæs-Fliflet, 2017.

39 Andenæs-Fliflet, 2017, 502. o.

40 A veszélyhelyzetekkel kapcsolatos felelősségi kérdések változására lásd: Magnussen, 2005.

41 Lásd erről részletesebben a NUO honlapját: www.regjeringen.no/no/dokument/nou-ar/id1767/ (Letöltve: 2020. december 15.).

42 NOU, 2019.

43 NOU, 2019, 57-95. o. 
zések érvényesítésével összefüggésben, és ezek fényében szükség van-e módosításra, illetve hogy a jelenlegi vészhelyzeti felkészülési rendszerek mellett ágazati szinten szükséges-e ezen tevékenységek jogalapjának megteremtése. A jelentés érintette a vészhelyzetre való felkészülést, ezenbelül az önkormányzati és regionális egészségügyi szolgáltatásokat, az Eü. felkészültségi tv.-t, a fertőzéskontroll kérdését, valamint az ipari felkészültséget szabályozó rendelkezéseket - többek közt a különleges intézkedésekról szóló határozatokat, a polgári védelmet, a nyilvánosság segítségnyújtási kötelezettségét vészhelyzet esetére, a szolgálati kötelezettség vészhelyzetben történő igénybevételét -, a nukleáris baleseti felkészültséget, a biztonság és hírszerzés körét. Vizsgálta az egyes ágazati szereplőket, így a rendőrség, túzoltóság, határellenőrzés munkáját, valamint a bevándorlást szabályozó törvényeket. Ezen túl külön alfejezet foglalkozott az energia- és áramellátás, a közlekedési, infrastruktúra- és kommunikációs hálózatok, a média, a banki és pénzügyek, a természet- és környezetvédelem releváns területeivel.

A 8. fejezet ${ }^{44}$ a speciális kompetencia- (hatásköri) alapokat vette górcső alá. Azaz az előző (7.) fejezetben említett rendkívüli esetekre vonatkozó jogszabályok releváns részei a 8. fejezetben tárgyalt hatásköri rendelkezésekre figyelemmel alkalmazhatók. Így például a 8.2. pont írja le a király számára az ideiglenes rendeletek alkalmazhatóságát azokban az esetekben, amikor a parlament nem ül össze. A 8.3-8.5. pont határozza meg a háború, politikai válság vagy a rendkívüli helyzet esetén követendő jogi rendelkezéseket (amelyekre korábban már utaltunk). A 8.5. pont az alkotmányos sürgősségi joggal, a 8.6. pont a vészhelyzeti szabályozással foglalkozik.

A jogszabályi keretek kapcsán a jelentés több kritikai megjegyzést is tett. Rögzítette, hogy a Vészhelyzeti felkészültségi tv. az alkotmány egyes releváns rendelkezéseinek konkretizálását célozza. E vonatkozásban a hatalom súlyos válsághelyzetben való gyakorlásának szabályozása a kiszámíthatóság és a jogállamiság szempontjából indokolt. Ugyanakkor az alkotmányos szabályozás szúkössége okán (például rendkívüli állapot elrendelése) nincs „pozitív joga” a békeidejú szabályoktól való eltérésre. Ez kihat az egyéb felkészültségi szabályok alkalmazhatóságára is, s mindig konkrét, egyedi, diszkrecionális értékelésen múlik, hogy a rendes körülmények között az alkotmány megsértését okozó cselekedet a vészhelyzet következtében indokoltnak minősül-e. Elutasításra került az Emberi Jogi Bizottságnak az alkotmány ez irányú módosítását célzó javaslata, ${ }^{45}$ míg a Vészhelyzeti felkészültségi tv. megalkotásakor az Igazságügyi Bizottság több tagja állt ki amellett, hogy a kríziseket teljeskörúen lefedô szabályozás kivitelezhetetlen a veszélyhelyzetek sokszínú és eltérő volta miatt. ${ }^{46}$ Pedig

44 NOU, 2019, 78-83. o.

45 A javaslat szerint az alkotmány kiegészült volna azzal, hogy a garantált jogoktól való eltérésre akkor kerülhet sor, ha egy kihirdetett háború vagy válsághelyzet nyilvánvalóan szükségessé teszi azt a demokrácia, a jogállamiság és a királyság létének biztosítása érdekében (NUO, 2019, 81. o.).

46 A bizottság javaslatai a születő Vészhelyzeti felkészültségi tv.-hez (Innstilling fra justisnemnda til midler tidig lov om særlige rådgjerder under krig, krigsfare og lignende forhold 1950); hivatkozza: NUO, $2019,81.0$. 
a felkészültségi törvények számos alapjog-korlátozó intézkedési lehetőséget nevesítenek. Így például a rendőrségi törvény széles körú - eljárási korlátozások nélküli - beavatkozást biztosít a közrendsértések megfékezésére, illetve arra az esetre, ha olyan körülmények állnak fenn, amelyek az ilyen rendzavaró magatartásokhoz kapcsolódóan félelmet idéznek elő. A jelentés ezen túl is komoly jogi hiányosságokra hívta fel a figyelmet a rendőrségi törvény kapcsán, például a drónhasználatot vagy a rádiójelek blokkolását illetően.

A második nagy terület a krízishelyzetekben történő koordinációt felölelő katasztrófavédelem. Ez mind országos, mind regionális szinten jól szervezett, állami és civil szervezetek és az állampolgárok aktív részvételén és szervezett tevékenységén alapuló rendszer. A 2003-ban országos felhatalmazással alapított tønsbergi Polgári Védelmi és Vészhelyzeti Felkészültségi Igazgatóság (DSB) ${ }^{47}$ célja a társadalmi kockázatok és sebezhetőség teljes áttekintése, a balesetek, válságok és más nem kívánt események megelőzését célzó intézkedések előmozdítása, valamint a megfeleló vészhelyzeti tervezés, illetve a balesetek és krízisek hatékony kezelése. Ennek érdekében a szervezet támogatja az Igazságügyi Minisztériumot és a rendőrséget koordinációs szerepük ellátásában, kidolgozza és múködteti a nemzeti vészhelyzeti felkészültségi és reagálási terveket, tanácsot ad és jelentést készít a minisztérium és a kormány felé a nemzeti válságkezeléssel kapcsolatban.

Megyei szinten a helyi ügyekért felelős, az állampolgárok által választott megyei tanács, illetve a király és a kormány képviselőjeként a parlament és a király által kinevezett, a kormány döntéseinek megyei szintú végrehajtásáért felelős kormányzó egyaránt részt vesz a munkában.

A DSB nagyon széles körủ és összetett feladatai közül kiemelendő a szervezési, koordinációs, ellenőrzési, nyomon követési stb. tevékenységek, a nemzeti sebezhetőség kialakulásával és a változó fenyegetési forgatókönyvekkel kapcsolatos kutatások, tanulmányok és dokumentációk létrejöttének támogatása - enélkül nem lehetne eredményes a reagálás és a prioritások megtervezése. (Így célorientált kapcsolatrendszerrel más, a területen releváns aktivitást folytató olyan civil szervezetekkel is együttmúködik, mint például a NORSAR [Norwegian Seismic Array] nemzetközileg elismert, független, a geotudományok, a szeizmológia, az alkalmazott geofizika nonprofit kutatási alapja.) Ugyanakkor a minőségbiztosítási szempontok is komoly szerephez jutnak, amennyiben az igazgatóság stratégiai menedzsmenttel kapcsolatos válságkezelési és válságkommunikációs gyakorlatokat tervez és vezet mind nemzeti, mind regionális, mind helyi szinten.

A szervezet jelentőségét mutatja, hogy tevékenységének ellátása során olyan szakintézmények munkájáért is felel, mint például a Norvég Polgári Védelem (Norge Sivilforsvaret), a Nemzeti Közösségi Biztonsági és Vészhelyzeti Felkészültségi Oktatási Központ (Nasjonalt Utdanningssenter for Samfunnssikkerhet og Beredskap) vagy a Norvég Túzoltó-akadémia (Norges Brannskole). Nemzetközi szinten is lát el feladatokat; így a Norvég Támogatói Csoport (Norsk

47 Direktoratet for Samfunnssikkerhet og Beredskap (DBS) (A szervezet honlapja elérhetô: www.dsb.no/). 
Support Team) első határon túli feladata a koszovói válságot követően kialakult helyzetben tábor létesítése az ENSZ segélyszervezetei számára.

A DSB múködését már a kezdetektôl több jogszabály is rögzíti, ${ }^{48}$ de a szervezet maga is fontos szerepet tölt be a katasztrófavédelem szempontjából releváns szabályok betartása érdekében. A szervezeti alá- és fölérendeltségi kérdések pontosan meghatározottak, így nem jelent problémát az együttmúködés az olyan, önmagában is integrált koordinációs struktúrát múködtető szakmai szervezetekkel, mint a Norvég Kereső- és Mentőszolgálat (Norsk søk-og redningstjeneste). ${ }^{49}$ Segítségével minden egyes mentési koordinációs központ felkészült a szárazföldi, tengeri vagy légi múveletek, a tengeri olaj-vagy gázipari létesítmények mentési és a nemzetközi együttmúködést igénylő egyéb múveletek kezelésére.

A nemzet sebezhetőségének és fenyegetettségének meghatározásakor kiemelkedő jelentősége van a kockázatértékelésnek. Erre figyelemmel Norvégia a kockázatértékelés több formáját $t^{50}$ is alkalmazza - így a biztonság és védelem területén is folyamatosan készülnek kockázatelemzések. Ezek ${ }^{51}$ részben arra is fókuszálnak, hogy a két igény - biztonság és védelem - tekintetében mennyiben azonosak, illetve különbözőek a kockázati tényezők és a kezelési lehetőségek. Számtalan esemény következhet be, amelyek különböző mértékben érinthetik a két igényt; így szélsőséges időjárás, áradások, földcsuszamlások, fertőző betegségek, erdei tűz, időjárási körülmények, vulkáni tevékenység, földrengés, veszélyes anyagok, atombalesetek, tengeri balesetek, közlekedési balesetek, áramszolgáltatás, terrorizmus, politikai válságok, digitális támadások. Ennek megfelelően például 2018-ban 27 kockázatelemzés történt 17 kockázati területen belül, ${ }^{52}$ amelyek során több szempont is értékelésre került: a fenyegetés valószínűsége, a biztonsági rés nagysága és a lehetséges következmények, amelyek együttesen megadják az ország vagy az adott szektor sebezhetőségét is. Ugyanakkor annak meghatározása, hogy az esemény bekövetkezte mennyire valószínú, bár komoly háttérismereten kell alapuljon, hordoz magában bizonyos fokú szubjektivitást is. Ennek ellenére mind társadalmi, mind közösségi, mind akár gazdasági-piaci szereplői ${ }^{53}$ területen kiemelkedően fontos. 2020-ban - még a Covid-19 megjelenése elôtt - készült nemzeti fenyegetésérzékelési vizsgálat ${ }^{54}$ a norvég biztonságot veszélyeztetô legsúlyosabb fenyegetések három formáját azonosította: a kormányra, a parlamentre és a fegyveres erőkre irányuló külföldi hírszerzési

48 Lásd erről részletesebben az Európai Bizottság honlapját: https://ec.europa.eu/echo/files/civil_protection/ vademecum/no/2-no-1.html (Letöltve: 2020. szeptember 10.).

49 Ez egyben biztosítja Norvégia aktív részvételét a tengeri kutatásról és mentésról szóló 1979-es nemzetközi SAR-konvenció végrehajtásában (International Convention on Maritime Search and Rescue).

50 Lásd a nemkívánatos szándékos tevékenységek kockázatértékelésének megközelítéseire például: Busmundrud et al., 2015.

51 Midtgaard, 2018.

52 Így többek között a pénzmosás és a terrorizmus finanszírozása kérdéskörben is. Lásd erről részletesebben: www.regjeringen.no/contentassets/58f96ea9756d4457be3095609624d96d/nasjonal-riskikovurdering.pdf (Letöltve: 2020. december 15.).

53 Lásd például: Holter, 2010.

54 PST, 2020. 
aktivitást, a kritikus infrastruktúrák digitális felderítésének és szabotálásának veszélyét, valamint a terrorista támadások lehetőségét, amelyeket jobboldali szélsőségesség vagy szélsőséges iszlamista ideológia motivál.

Az év során - már a pandémia időszakában - a Nemzetbiztonsági Bizottság5 által készített kockázatértékelés ${ }^{56}$ az ország fokozott sebezhetőségét a digitalizációban, illetve a nemzeti (vállalati) értékek, a társadalom legtöbb szektorában a funkciók és szolgáltatások virtuális térbe való helyezésében látja. A külföldi államok befolyásolási törekvései, a hírszerző szolgálatok kutatási és technológiafejlesztési környezetekhez való hozzáférési kísérletei, az érzékeny információk és üzleti titkok megszerzésének célja nem új keletú jelenség, mértéke és intenzitása - a mindennapi tevékenységek digitális térbe szorulása miatt is -, illetve jelentősége 2020-ban tovább fokozódott. Így a jelentésben nevesített mindhárom fó nemzetbiztonsági kockázati tényező a kiberbiztonsághoz kapcsolódik: a társadalom növekvő függősége az elektronikus hírközléstől és a múholdas alapú szolgáltatásoktól; a digitális infrastruktúráktól és a határainkon túli értékláncoktól való fokozódó függés; az együttes eszközhasználat, többek között stratégiai akvizíciók, beruházások és befolyás formájában.

\section{A különleges jogrend kihirdetésének gyakorlati esetei}

Különleges jogrend kihirdetésére, szükségállapot, rendkívüli állapot elrendelésére a rendelkezésre álló információk szerint Norvégiában az elmúlt időszakban különböző okok miatt még a járványhelyzetet megelőzően nem került sor.

A különleges jogrend alkalmazását megalapozó esetek tekintetében az ország fekvéséből és energiaipari pozicionálásából adódóan elsősorban a természeti és ipari katasztrófák jelennek meg különös súllyal. A természeti katasztrófák közül az utóbbi időben a klímaváltozás okoz gondot - így például a világ különösen gyorsan melegedő területén, a Spitzbergákon rénszarvasok százai halnak éhen, míg más területeken komoly földmozgások, hegyomlások miatt kell embereket evakuálni. ${ }^{57}$ Ugyanakkor a kormány mára nemcsak komplex rendszert dolgozott ki az ilyen helyzetek kezelésére, de proaktivitás ${ }^{58}$ is jellemzi. Az elmúlt években egységesített katasztrófavédelmi rendszer kialakítását olyan ipari katasztrófák is segí-

55 Nasjonal sikkerhetsmyndighet (NSM).

56 NSM, 2020, 5. o.

57 Így legutóbb például a Veslemannen hegycsúcs leomlása miatt. Elérhető:https://hvg.hu/tudomany/20190908_ Hegyomlas_evakualas_elo_adas_Norvegiaban (Letöltve: 2020. november 11.).

58 A kormány tulajdonában lévő Globális Terménydiverzitási Szövetség (Global Crop Diversity Trust) látja el a Svalbargi Globális Magtár (SGSV) múködtetését, amely több mint 800 ezer növényfaj magmintáját őrzi abból a célból, hogy egy globális katasztrófa (például atomháború, földrengés vagy világméretú járvány) bekövetkezte esetén is megőrizze az emberiség a termények biológiai sokszínűségét. Az ötlet több mint 30 éves; a skandináv országok 1984-ben már létrehoztak egy magtárolót a szigetcsoport egyik elhagyatott szénbányájában. Elérhető: http://ecolounge.hu/nagyvilag/a-spitzbergaki-globalis-magbunker (Letöltve: 2020. november 11.). 
tették, mint az úszó hotelként funkcionáló Alexander L. Kielland félig merülő fúrótorony 1980. március 27-i elsüllyedése. ${ }^{59}$

Az ország békés, belső és külső támadásoktól mentes mindennapi élete 2011-ben azonban jelentősen megváltozott. A kiugróan jó közbiztonsági helyzetet jól jellemzi, hogy például 2010-ben összesen 29 emberölést követtek el (a kétszer olyan nagy lélekszámú Magyarországon 150-et), ${ }^{60}$ és a rend fenntartása érdekében a norvég rendőrök az 1994-2004 közötti 10 év alatt - a 2004-es stavangeri NOKAS-bankrabláson kívülli - csupán 31 alkalommal használták fegyvereiket. Bár terrorcselekményként minősíthető bűncselekmények elkövetésére is akadt példa, ${ }^{62}$ ezek száma csekély volt: 2004-2010 közötti adatok alapján Norvégia a Worldwide Incident Tracking System (WITS) terrorizmus-adatbázisában sem szerepelt. Ahhoz, hogy mára a különböző kihívásokra megfelelően felkészült legyen, sokat „tett hozzá” Anders Behring Breivik 2011. július 22-i, az országot teljesen váratlanul érő és sokkoló, Oslóban és Utøya szigetén elkövetett merénylete. A 77 halálos áldozatot és 96 sebesültet követelő bưncselekmény létrejöttében ugyanis jelentős szerepet játszott számos körülmény, így a lőfegyverhez jutás nagyon liberális feltételei; az a tény, hogy a norvég rendőrök alanyi jogon nem viselhetnek fegyvert; a több száz fôs ifjúsági tábort csupán egyetlen, fegyver nélküli rendőr biztosította; a rendőrök által igénybe vett utazási eszköz és a különleges erők által választott helyszín téves volta; a fiatalokat mentő helyi civilek tevékenységének leállítása a különleges erők megérkeztéig. Összességében szervezetlen, nem kellően összehangolt és felkészületlen volt a hatóság reagálása a cselekményre, ami önvizsgálathoz és több változtatáshoz is vezetett.

Más történések is a minőségbiztosítási szempontok belső fókuszba állitását igényelték. Bár a norvég kormány krízishelyzeteket kezelő mechanizmusa már korábban is jól kimunkált volt, a potenciális (például környezet- és egészségkárosító) rizikótényezőként megjelenő esetek egy részére csak áttételes hatása lehetett. ${ }^{63}$ Ezek egyik legsúlyosabbika a K-278-as jelzésú, harmadik generációs atom-tengeralattjárók közé tartozó Komszomolec 1989. április 7-én a norvég fennhatóság alatt álló Medve-szigetek közelében történő elsüllyedése. A hadijármú a hagyományos és nukleáris robbanófejjel egyaránt felszerelhető torpedókon kívül

59 A 123 emberéletet követelő katasztrófa létrejöttéhez számtalan tényező vezetett: a tornyot tartó egyik láb megrepedt; ezt a tényt a torony múszaki felülvizsgálatakor nem észlelték, mivel a lábakat nem ellenőrizték (inadekvát biztonsági ellenőrzések); a műszaki leírásban nem szerepelt, hogy mekkora megterhelésnek lehet kitenni a platformot; nem volt elég hozzáférhető mentőmellény, és nem volt olyan vészforgatókönyv sem, amit elpróbáltak és egységesen követhettek volna az ott dolgozók. Elérhető: https://iparikatasztrofak.blog. hu/2017/12/13/igy_sullyed_el_egy_furotorony_15_perc_alatt (Letöltve: 2020. november 11.).

60 Tálas et al., 2011, 1. o.

61 Itt 48 alkalommal került rá sor.

62 A Global Terrorism Database (GTD) szerint 1979 és 2010 között 15 terrorcselekmény, ezen belül két robbantásos merénylet volt (1987, 1994), amelyek 17 áldozatot követeltek (köztük egy halálos). Tálas et al., 2011, 2. o.

63 A számos szovjet/orosz tengeralattjáró-baleset széles körủ kihatásait jól mutatja, hogy például a 2000. augusztus 12-én az orosz hadsereg Barents-tengeren tartott hadgyakorlata során elsüllyedt Kurszk atom-tengeralattjárón történt robbanásokat a norvég földrengés-megfigyelő rendszer azonnal észlelte, míg Oroszország hivatalosan csak két nappal később jelentette be a tragédiát. 
képes volt atomtöltettel rendelkező interkontinentális ballisztikus rakéták indítására is, így a roncsok komoly ökológiai veszélyforrást jelentenek. ${ }^{64}$

Az említett esetek közül önvizsgálatot ${ }^{65}$ és intenzív társadalmi és szakmai diszkussziót leginkább a Breivik-ügy - illetve az azzal kapcsolatban feltárt rossz múködési mechanizmusok köre - váltott ki.

Az utóbbi időszakban az ország közbiztonsági helyzete a külső és belső társadalmi változások hatására - bár csekély mértékben, de - negatív irányban változott; emellett az esetleges vészhelyzetet előidéző támadások részben más síkra terelődtek. Ennek hatására 2019 novemberében a Nemzetbiztonsági Bizottság részeként megalakult a Nemzeti Kiberbiztonsági Központ (Nasjonalt cybersikkerhetssenter).

Ezen, összességében pozitív folyamatok ellenére a különleges jogrend szabályozását, annak tartalmi kérdéseit, esetköreit és a vészhelyzetekben való gyakorlati alkalmazhatóságát érintően számtalan kritika ${ }^{66}$ fogalmazódott meg már a korábbi évek során is.

Élénk - politikai, szakmai - vitát generált a közelmúltban a külföldi katonai szerepvállalás kérdése. Az alkotmány 25. cikkének módosítása azért merült fel, mert bevett gyakorlattá vált a norvég katonák külföldre irányítása a parlament döntése nélkül. ${ }^{67} \mathrm{Az}$ alkotmány szigorú értelmezése szerint Norvégia külföldi háborús részvételéről a parlament dönt, nem pedig a kormány. A norvég katonák azonban - mint NATO-tagok - részt vettek és vesznek különböző nemzetközi rendfenntartó akciókban, aminek a nemzetet megérintő érzelmi következményei is vannak; például 2001-2012 között 10 norvég katona vesztette életét Afganisztánban ${ }^{68}$ a NATO vezette nemzetközi biztonsági erôk tagjaként. Ugyanakkor az alkotmány sem a norvég katonák külföldre küldését, sem külföldi katonák érkezését nem támogatja. Ennek ellenére - a II. világháború óta először - 2017 januárjától amerikai tengerészgyalogosok állomásoztak ${ }^{69}$ az ország területén. A javasolt alkotmánymódosítás célja a helyzet tisztázása, az átláthatóbb és demokratikusabb parlamenti vitához való hozzájárulás, egyben olyan biztonsági „szelepek” beiktatása volt, amelyek garantálhatják a kormány gyors cselekvési képességét - akár az ország határain kívül is, ha ez indokolt -, kifejezetten Norvégia határainak védelme érdekében. ${ }^{70} \mathrm{Az}$ így módosított és jelenleg hatályos alkotmány már rögzíti a parlament hatalmát, és egyben kizárja, hogy parlamenti jóváhagyás nélkül a norvég fegyveres erők ,idegen hatalmak szolgálatába álljanak”, avagy idegen hatalom ka-

64 Lásd erről részletesebben például: Múlt-Kor, 2019.

65 A kormány felelősségéról és más kérdésekről lásd részletesebben: Lægreid et al., 2014, 66-77. 0.

66 Lásd erről részletesebben: Wind, 2009, 131-141. o.

67 A külföldön zajló norvég háborús részvétel kapcsán nagyobb átláthatóságot elérni kívánó alkotmánymódosító javaslatra lásd: www.stortinget.no/no/Saker-og-publikasjoner/Publikasjoner/Innstillinger/ Stortinget/2015-2016/inns-201516-287/?lvl=0 (Letöltve: 2020. szeptember 6.).

68 Elérhetô: https://honvedelem.hu/cikk/norveg-katonakra-tamadtak-afganisztanban/ (Letöltve: 2020. szeptember 27.).

69 Elérhető: https://hu.euronews.com/2018/06/12/tobb-amerikai-katonat-ker-norvegia (Letöltve: 2020. szeptember 27.).

70 Lásd a fentebb hivatkozott alkotmánymódosító javaslatot. 
tonái a királyság területére lépjenek (még ha ellenséges támadások ellen fellépő csapatok tagjai is). Kivételt jelentő eset, hogy a királyság védelmi erőit a királyság határain kívül használhatják a parlament beleegyezése nélkül is, amennyiben ez az ország védelme érdekében feltétlenül szükséges.

A különleges jogrenddel kapcsolatos konkrét ügyeket érintő jogvitákra a norvég legfelsőbb bíróság előtt kerülhet sor. Tønder legfelsőbb bírósági bíró erre vonatkozó tanulmányában ${ }^{71}$ is rögzíti a törvényhozó és a végrehajtó hatalom norvég bíróságok általi ellenőrzésének speciális jellegét. A törvényhozó hatalom tekintetében ez annak biztosítását jelenti, hogy a jogalkotás összhangban van az alkotmánnyal, a végrehajtó hatalom vonatkozásában pedig a polgárokkal szembeni közhatalom gyakorlásának a közigazgatási jog hatáskörébe tartozását. „Norvégia tehát nem rendelkezik közigazgatási bíróságokkal a hatalom nyilvános gyakorlására vonatkozó esetek megvizsgálására, sem alkotmánybíróságokkal alkotmányos kérdések kezelésére."ᄁ2 Egyebekben a rendes bíróságok felülvizsgálják a jogszabályok kapcsolatát a norvég jog részévé vált emberi jogi egyezményekkel, valamint az ország EU-val kötött megállapodásával is.

A különleges jogrendet érintő esetkörök közül példaként említhető az a terrorista cselekmények elkövetésével kapcsolatos konkrét büntetőügy,73 amely indoklásában - egyes törvényhelyek értelmezésbeli különbözésével összefüggésben - kifejtésre került, hogy nem volna szerencsés, ha Norvégia jelentené a „rést”"74 az európai országok (és az EU) terrorizmusellenes szabályozásában.

A kimondottan stabil államtörténelemmel bíró Norvégiában az 1814. évi alkotmány veszélyhelyzeti vagy rendkívüli körülmények alatti müködését elsősorban az 1940-1945 közötti háborúban „tesztelték”. Bár a pandémia megjelenése teljesen más támadást jelent, az egész országot és annak minden müködési szintjét érintő jellege olyan új helyzetet váltott ki, amely komolyan megmérette a norvég szabályozást, rég nem tapasztalt heves tiltakozást kiváltva és mintegy előtérbe hozva a sürgősségi jogalkotás kérdését (amely már korábban is a szakmai-tudományos környezet kiemelt figyelmében állt).75

Az alkotmányokat általában egy ország megszokott múködési feltételeire írják, s így sokszor gondot jelent a rendkívüli helyzetek generálta rendkívüli igények kielégítése legyen szó természeti katasztrófákról, politikai zavargásokról, háborúkról vagy terrorista akciókról. Nemzetközi szinten is igaz, hogy a rendkívüli helyzetek az alkotmány - ideiglenes - „felfüggesztésének” egyik tipikus okává váltak. Ezt a folyamatot tovább erősítették

71 Részletesebben lásd: Tønder, 2014, 74-84. 0.

72 Tønder, 2014, 74. o.

73 Lásd a legfelsőbb bíróság HR-2018-1650-A (case no. 18-044407STR-HRET) számú ítéletét: www.domstol.no/ globalassets/upload/hret/decisions-in-english-translation/hr-2018-1650-a.pdf (Letöltve: 2020. november 11.).

74 Norvégiát tehát egyfajta „biztonságos menedéknek” lehet tekinteni, ahol bizonyos korlátok között propagandatevékenység fejthető ki.

75 Michalsen, 2013. 
a 2001 után egyre gyakoribbá váló - immár direkten a kormányokat célzó - terrorista akciók, amelyek kiterjedt nemzeti és nemzetközi jogalkotásra ösztönözték az államokat. ${ }^{76}$ Így számos országban - beleértve Norvégiát is - az „alkotmányos szükségesség” a sürgősségi törvényhozás egyik változatává vált, amely felhatalmazást ad a kormánynak az alkotmány egyes részeinek felfüggesztésére. Ez a gyakorlat azonban már eddig is komoly garanciális kérdéseket vetett fel, elsősorban az alkotmányos jogállamiság és az állam biztonság iránti igénye közötti egyensúlyteremtés kapcsán; a járványkezelés lehetséges válaszaként pedig kétségessé tette annak alkalmazhatóságát.

A járványhelyzet kezelésével összefüggésben Norvégiában nem került sor sem különleges jogrendi szabály alkalmazására, sem rendkívüli állapot elrendelésére. Utóbbit a norvég alkotmány nem ismeri, míg előbbi kapcsán is csekély számú konkrét rendelkezést tartalmaz. Az egészségügyi vészhelyzet kezelését - mint sok más országban - itt is a rendes jogszabályok határozzák meg, így többek között a Fertőzéskontroll tv. és az Eü. felkészültségi tv. Ezek kiterjedt hatáskörökkel ruházzák fel a kormányt. Bár - ahogy már rögzítettük - az alkotmány nem ismeri el az emberi jogoktól való általános eltérési záradékot, elméletileg egy egészségügyi veszélyhelyzet, amennyiben ennek súlyát úgy ítélik meg, lehetőséget adhat az úgynevezett alkotmányos szükségesség elve alapján az alkotmányban rögzítettektől eltérő jogalkotási gyakorlatra az arányosság követelményének szem előtt tartásával. 2020 szeptemberéig 10 tagállam jelentette be, ${ }^{77}$ hogy az EJEE 15 . cikke alapján a feltételek ${ }^{78}$ szigorú betartásával ideiglenesen eltér szokásos egyezményes kötelezettségeitől a Covid-19-cel szembeni eredményes fellépés érdekében, de Norvégia nem csatlakozott e körhöz.

Elsősorban a járványkezelés konkrét módját illetően számos kritika fogalmazódott meg. Ezek közül a legélesebbek egyenesen azt üzenték, hogy a norvég hatalom eljárása ez esetben nemcsak az egészséget, hanem a jogállamiságot is támadja. ${ }^{79}$ Norvégiát mint rossz példát állították ki, amely veszélyeztetheti a Covid-19-cel szembeni intézkedések elfogadásának demokratikus folyamatát, s olyan jelenségekkel átitatott, mint a hatóságok hatásköri túllépései, az átláthatóság hiánya és a nyilvánosság kizárása a döntéshozatalból, valamint a központi kormányzat és a helyi hatóságok közötti folyamatos küzdelem a szabályozás „birtoklásáért”.

Természetesen a járvánnyal szembeni intézkedések Norvégiában is az ismert eszközöket vették igénybe ${ }^{80}$ a karantén elrendelésétől a boltok, intézmények bezárásáig. ${ }^{81}$ A rendel-

76 Érdekes tény, hogy Izlandon például a 2000-es évek során bekövetkezett pénzügyi válság vezetett el a sürgősségi jogalkotás elfogadásához. Lásd errôl részletesebben: Krunke et al., 2018.

77 Ezek a következők: Albánia, Örményország, Észtország, Grúzia, Lettország, Észak-Macedónia, Moldova, Románia, San Marino és Szerbia (Radjenovic-Eckert, 2020).

78 Lásd erre részletesebben: Jovičić, 2020.

79 Lásd erre részletesebben: Graver, 2020 a.

80 A koronavírus-helyzettel kapcsolatos legfontosabb információk és reakciók elérhetők norvég nyelven a következő honlapon: www.regjeringen.no/no/tema/Koronasituasjonen/id2692388/ (Letöltve: 2020. december 15.).

81 Lásd erről részletesebben: www.regjeringen.no/en/topics/koronavirus-Covid-19/timeline-for-news-fromnorwegian-ministries-about-the-coronavirus-disease-Covid-19/id2692402/ (Letöltve: 2020. december 15.). 
kezések alapját elsősorban a Fertőzéskontroll tv. adta, így különösen annak 4. fejezete (Egyéb fertôzésvédelmi intézkedések). Ez széles körben nyújt felhatalmazást alapjogok korlátozásával való intézkedések alkalmazására, azok jellegétől függően az önkormányzati tanácsot, a Járványügyi Központot, a megye kormányzóját vagy épp a királyt felruházva a döntéshozatal jogával. ${ }^{82} \mathrm{Az}$ iskolákat és óvodákat bezárták, a gyülekezést ugyanúgy tiltották, mint például a különböző, közvetlen emberi interakciókat feltételező szolgáltatásokat (például fodrász, fogorvos, edzőterem igénybevétele). Ugyan általános kijárási tilalmat nem rendeltek el, de arra ösztönözték a lakosságot, hogy kerüljék a tömegközlekedést, vegyék igénybe a home office-t, és ne fogadjanak otthonukban vendégeket. Ezzel párhuzamosan módosították az eljárási törvényeket a közigazgatást és a közszolgáltatásokat (például igazságszolgáltatás, oktatás) érintően, széles körben lehetővé téve a virtuális kommunikációt és feladatellátást. Pozitív hatásként értékelhető, hogy Norvégia jelentős gazdasági támogatást is nyújtott az érintett gazdasági szereplók és munkavállalók számára.

Ugyanakkor a számtalan Covid-19 tárgyú rendelet, illetve törvénymódosítás jelentős alapjog-korlátozó elemeket is tartalmazott. Így például a koronavírus kitörésével összefüggő, a fertőzés elleni intézkedésekről szóló, 2020. március 27-i 470. sz. rendelet a beutazási és karaténszabályok vonatkozásában vagy a Covid-19 kitörése következményeinek orvoslását célzó integrációról szóló törvény módosítása. ${ }^{83} \mathrm{E}$ körben fontos kiemelni, hogy például az országot 2020. március 12-ével lezáró határozatot hivatalosan a Norvég Egészségügyi Igazgatóság hozta meg, noha az alkotmány értelmében az ilyen döntések a kabinet hatáskörébe kell tartozzanak. A Fertőzéskontroll tv. kereteit az állam és a helyi hatóságok (is) a végletekig kitágították. ${ }^{84}$

Az intézkedések tehát jellegükben és irányukban nem tértek el más országok gyakorlatától, azonban az emberi jogokra igen érzékeny országban ${ }^{85}$ nagyon hamar megjelentek az első kritikák. ${ }^{86}$ Ezek középpontjában először az arányosság kérdése állt. A helyi szokásoknak és életvitelnek megfelelóen a norvég - fóként városi - lakosság tipikusan rendelkezik egy hyttével, azaz hétvégi házzal a hegyekben vagy a tenger mellett, ahol eltölti az ünnepeket, vagy egyszerúen hétvégén kikapcsolódik. A szabad mozgást korlátozó rendelkezések jelentősen érintették ezt a szokást, elsősorban annak érdekében, hogy az egyébként általában

82 Lásd az önkormányzati szabályozással kapcsolatos kormányzati ajánlásokat részletesebben: Nicolaisen et al., 2020.

83 LOV-2020-12-18-154. A Covid-19 kezelésével összefüggésben született, a gazdaságot érintő jogszabályok listája elérhető például a következő honlapról: www.skatteetaten.no/en/measures/ (Letöltve: 2020. december 15.). 84 Graver, 2020b, 167. o.

85 Ez alapján Norvégia a második helyen állt 2019-ben és 2020-ban is a World Justice Project (WJP) jogállamisági indexe szerint (WJP, 2020, 7. o.). Ugyanakkor a legfőbb jogállami kihívások között szerepel a hatóságok hatáskörének túllépése, az átláthatóság hiánya és a nyilvánosság kizárása a nyilvános döntéshozatalból és a joghatóság feletti harc a központi kormányzat és a helyi hatóságok között.

$86 \mathrm{Az}$ Oslói Egyetem Norvég Emberi Jogi Központja (Norwegian Centre for Human Rights) fokozott figyelemmel kíséri a járványkezelést. Az ezzel kapcsolatos tanulmányok elérhetők a szervezet honlapján:www.jus.uio.no/ smr/english/?vrtx=search\&query=Covid-19 (Letöltve: 2020 . december 15.). 
ritkán lakott, zárt vidéki közösségeket megóvják a nagyobb népsűrűségú, így nagyobb fertőzésveszélynek kitett városi lakosokkal való érintkezéstől. Ezek a rendelkezések több alapvető - társadalmi és gazdasági jellegû - jogot is érintettek, így 10 nappal a hatálybalépést követően az Emberi Jogi Intézet igazgatója már megfogalmazta aggályait. Ezek középpontjában elsősorban az állt, hogy a kormány a rendelet elfogadása előtt nem tárt fel elegendő bizonyítékot az intézkedések szükségességének és arányosságának indoklására. A kormány arra hivatkozott, hogy a területek egészségügyi szolgáltatásai nem készültek fel az esetlegesen ott megbetegedő hétvégi nyaralók megnövekedett számának ellátására. Noha a vita végén az Államtanács is elismerte, hogy az egészségügyi szolgáltatások kapacitásvédelme más módon is biztosítható, s ezek mérlegelését az előkészítés során nem vizsgálták, de a rendeletet ezzel együtt nem módosították.

A Fertőzéskontroll tv. alapján a király számos jogkörrel felruházott ugyan, az így hozott rendelkezéseket ugyanakkor a lehetô leghamarabb be kell nyújtani a parlamentnek, hogy az gyakorolhassa jogait, sor kerülhessen nyilvános konzultációra és a parlamenti felülvizsgálatra. A gyors kormányzati reagálás Norvégiában is lényeges szempont volt, így - a már ismert rendelkezéseken túl - számos jogszabály született, amelynek célja a hatékony fellépés volt. E körben különösen komoly kritikát ${ }^{87}$ váltott ki, hogy a kormány - a nyilvánosság szokásos tájékoztatása nélkül, az érintett intézményekkel való egyeztetés és érdekeik, illetve szükségleteik megismerését mellőzve - készítette el a vészhelyzeti törvény javaslatát, amely a sürgősségi jogalkotás hatásköreit is jelentősen érintette. Ennek során titkos üléseket tartottak; sőt, az ellenzéki pártok vezetőivel is megállapodtak annak érdekében, hogy a törvény akadály nélkül elfogadásra kerülhessen (a vita látszólagos lefolytatása mellett). A vészhelyzeti törvény a tervek szerint a kormányt jelentős jogkörökkel ruházta volna fel; egyrészt lehetőséget adva neki a jogszabályok parlament bevonása nélküli elfogadására, másrészt arra, hogy ha azt a társadalom múködési zavarainak korlátozása vagy épp a lakosságra, a gazdasági életre vagy a közszféra szereplőire háruló terhek enyhítése megkívánja, eltérhessen a hatályos törvények rendelkezéseitől. Új parlamenti ellenőrzési mechanizmusok kialakítását is tartalmazta a tervezet, lehetővé téve az elektronikusan (e-mail útján) történő hivatalos véleménynyilvánítást és joggyakorlást. A 2020. márciusi javaslattal szemben - különösen annak előkészítési módja okán - jelentős ellenérzések fogalmazódtak meg, kiemelve a tervezet alacsony szakmai színvonalát, sietős előkészítését, a magyarázatok és a háttérelemzések teljes hiányát. Elvi szinten különös súllyal jelent meg, hogy az nem felel meg a hatalomszétválasztás, a demokratikus biztosítékok és a jogállamiság elvének (legfeljebb súlyos kompromisszumok árán). A szakemberek számára a legaggályosabb üzenet az volt, hogy a kormány készen állt (volna) a törvényalkotás demokratikus folyamatának mellőzésére.

A törvényjavaslat 2020. március 18 -i előterjesztését követően ${ }^{88}$ azonban a fenti tények ismertté váltak, így a parlament a gyors meghallgatás kezdeményezése mellett döntött, 
amelyre meghívta képviselői révén többek között a Norvég Ügyvédi Kamarát, a Norvég Bírói Szövetséget, az Emberi Jogi Központot csakúgy, mint számos kiemelkedő jogtudóst, hogy véleményüket megismerhesse. Ezek beillesztésével alakítottak a javaslaton, s végül március 21-én a parlament el is fogadta a norvég korona- (Covid-19-) törvényt, amely azonban már jóval szükebb felhatalmazást ad a kormánynak a Covid-19 és annak társadalomra gyakorolt következményei elleni küzdelemre, mint az eredeti tervezet.

A számos ellenvélemény, szakmai aggály ellenére is fontos ugyanakkor kiemelni, hogy a végül elfogadott Covid-19-törvény több garanciális elemet tartalmaz ${ }^{89}$ a jogszabály érvényességi időtartamától kezdve (egy hónap) az alkalmazási előfeltételein át annak bírósági kontrolljáig. A folyamatosan módosuló, illetve rendeletekkel kiegészülő Covid-19-jogszabályok fố célja többek között a kompenzációt nyújtó gazdasági intézkedések elfogadása, a digitális bíróságok és igazgatás múködésének lehetővé tétele (például virtuális meghallgatások, digitális aláirás) vagy a bevándorlás-ellenőrzés aktuális intézkedési formáinak meghatározása volt. A törvénybe a parlament által beillesztett utólagos kontrollt erősítő rendelkezés kimondja, hogy a törvény szerinti intézkedések jogszerüségét és arányosságát teljes bírósági felülvizsgálatnak kell alávetni.

Egyéb - elsősorban a jogszabályok, konkrét rendeletek végrehajtásával kapcsolatos problémák is kritikai vizsgálat alá kerültek; így például a helyi intézkedések koordinálatlansága vagy a hatáskörtúllépések, amelyek jelentősen rontottak a Covid-19 elleni védekezés hatékonyságán.

\section{4. Összegzés}

A norvég alkotmány, mint a legidősebb Európában, felépítésében és szabályozási megoldásaiban visszatükrözi annak az országnak a békés történelmét, amely 21. századi múködési kereteinek alapját egy 1814-ben született alaptörvény testesítheti meg.

Ennek megfelelően az alkotmány nem tartalmaz részletes szabályokat a különleges jogrendet illetően, nem ismeri a rendkívüli állapot fogalmát, nem határoz meg vészhelyzeti rendelkezéseket, és elvétve szól a sürgősségi jogalkotásról. E tekintetben legjelentősebb szerepe az egyéb jogszabályoknak, így különösen a Vészhelyzeti felkészültségi tv.-nek van.

Mind az alkotmány, mind a Vészhelyzeti felkészültségi tv. speciális jogokat biztosít a királynak arra az esetre, ha például háború vagy háborús fenyegetés okán nem tudna ülésezni a parlament. Ez egyben azt is jelenti, hogy a király - meghatározott feltételek mellett - törvényerejü rendeleteket hozhat (akár az egyebekben hatályos és irányadó jogszabályi háttérrel ellentétes tartalommal is). E felhatalmazás korlátját számos rendelkezés garantálja, amelyek a parlament egyidejû tájékoztatásának és mihamarabbi összehívásának kötelezettségét

89 Graver, 2020b, 172-173. o. 
csakúgy rögzítik, mint a rendeletek hatályban maradásának időbeli korlátját. A jogokkal a gyakorlatban nem a király, hanem az Államtanács (azaz a kormány) él(ne).

Ezen túl a jogelmélet ismeri a szükségszerüség doktrínáját, amely szerint „a vészhelyzetek legitimálnak egy olyan tevékenységet, amely normál körülmények között az alkotmány megsértését vonná maga után". ${ }^{\circ 0}$ Fontos feltétel a súlyos vészhelyzet, valamint az, hogy a nemzeti érdekek védelme az irányadó jogszabályok betartása mellett nem garantálható. Így számos országban - beleértve Norvégiát is - az „alkotmányos szükségesség” a sürgősségi törvényhozás egyik változatává vált, amely felhatalmazást ad a kormánynak az alkotmány egyes részeinek időleges „felfüggesztésére”.

Bár Norvégiában a krízishelyzetek előfordulása ritka, azonban az ország - részben a 2011-es terrortámadásra is reagálva - iránymutató gyakorlatot alakított ki a vészhelyzetek megelőzése, illetve kezelése vonatkozásában, ahol mind az érintett komplex intézményrendszer, mind a feladat-, döntés- és felelösségmegosztás pontosan meghatározott. Ezek nemcsak az ágazati jogszabályokban rögzítettek, de a Vészhelyzeti Felkészültségi Bizottság jelentései, a katasztrófavédelem szabályozása is rögzíti ezeket. A komplex, széles körú hatósági és civil szervezeti körre és az állampolgárok bevonására épülő, többszintủ katasztrófavédelem és krízismechanizmus példaértékűnek tekinthető. Mindez jól kommunikált, áttekinthető szisztémaként múködik, amely biztosítja a folyamatos minőségbiztosítást, ${ }^{91}$ szükség esetén az újratervezést, utánkövetést, valamint az állampolgárok és szervezetek széles körú tájékoztatását.92

Az országban az emberi jogok és a jogállamiság kérdése kiemelten a figyelem középpontjában van, ennek ellenére a pandémiával kapcsolatos, alapvetően a Fertőzéskontroll tv.-en alapuló szabályozás, illetve a járványhelyzet kezelése az első időszakban számtalan kritikát kapott, és több szakmai aggály fogalmazódott meg, részben azok gyakorlati megvalósulásával kapcsolatban. A végül elfogadott Covid-19-törvény azonban már megfelel mindazoknak a garanciális szempontoknak, amelyek megalapozzák annak támogatottságát.

Elméleti síkon a norvég szabályozás sajátossága, hogy a parlament kontrollszerepét rögzítő garanciális korlátok mellett a döntés a király (kormány) hatáskörébe kerül, nagyon súlyos válság esetén pedig a szükségesség doktrínája gyakorlatilag minden hatalmat e körbe koncentrálhat, megengedve az alkotmány elveivel és rendelkezéseivel szemben álló döntés meghozatalát is. Az alkotmány fennállta óta erre azonban alig akadt példa. Sokkal inkább állítható Hans Petter Graver nyomán, hogy Norvégia a kivételek állama. ${ }^{93}$ Carl Schmitt gondolatai visszatükröződtek a norvég vészhelyzeti kodifikációs munkákban: csak normatív módon nem lehet előre szabályozni minden szükséghelyzetet; a kivételhez az általános

90 Andenæs-Fliflet, 2017, 502. o.

91 Így például: Cosgrave et al., 2008.

92 Lásd erre például: MOD, MOJ, 2018.

93 Graver, 2020b. 
normák által nem kötött döntés szükséges ${ }^{94}$ Hogy ez nem vezet szükségképpen diktatúrához, arra épp Norvégia lehet az egyik példa, amely Scheppele ${ }^{95}$ jogállamiság és a rendkívüli állapot közötti összefüggéseket felvázoló hármas tipológiájából a harmadik csoportba tartozik. Noha a Covid-19 vírussal szembeni fellépés során alapvető jogok túlzott korlátozására is akadt példa, sőt, a válsághelyzet megoldására való hivatkozás lehetőséget tưnt biztosítani a kormány hatalmának kibővítésére, a garanciális és jogállamisági szempontok ennek gátját szabták.

Bár „[a] hivatalos norvég alkotmány »régi kastélyként« jelenhet meg, de gyakorlata nem feltétlenül áll olyan távol a »stílusos modern operaháztól«" ${ }^{96}$ A parlamenti szuverenitás erős beágyazódása az alkotmány parlamenti szavazás útján történő módosításával, illetve a „negatív parlamentarizmus" pragmatikus elfogadása az alkotmányok speciális csoportjába sorolja a norvég alaptörvényt, amely azonban egyre inkább hasonlít más alkotmányokra többek között a jogok széles körének bírósági felülvizsgálatára való áttérés okán.

\section{Irodalomjegyzék}

ANDENÆS, J., Fliflet, A. (2017) Statsforfatningen i Norge. 11. kiadás. Oslo: Universitetsforlaget Busmundrud, O., MaAl, M., Hagness, J. K., Endregard, M. (2015) Tilnœerminger til risikovurderinger for tilsiktede uønskede handlinger. Kjeller: Forsvarets forskningsinstitutt

Cosgrave, J., LAegreid, T., Sørvald, M., BrusSet, E., Jørgensen, S. (2008) Evaluation of the Norwegian Emergency Preparedness System (NOREPS) - Evaluation Report 1. Oslo: Norwegian Agency for Development Cooperation

GERGELY, Á. (1994) Közép-Európa ígéret volt. 1. kiadás. Budapest: Balassi Kiadó

Graver, H. P. (2020a) Fighting the Virus and the Rule of Law - A Country Report on Norway [Online]. Elérhető: https://verfassungsblog.de/fighting-the-virus-and-the-rule-of-law-acountry-report-on-norway/ (Letöltve: 2020. december 1.)

Graver, H. P. (2020b) 'Covid-19 Regulation in Norway and State of Exception' in Serna de la Garza, J. M. (szerk.) Covid-19 and Constitutional Law. Mexico City: Universidad Nacional Autonoma de Mexico

94 Lásd erről részletesebben: Mehring, 2020a, 2020b.

$95 \mathrm{Az}$ első esetben a hatalom maga irányítja a helyzetet, ami végül rendkívüli állapothoz vezet. A második esetben a hatalom birtokosai szándékosan használják ki a valódi fenyegetést olyan intézkedések megtételére, amelyek meghaladják a tényleges veszély leküzdéséhez szükséges mértéket. Az előbbi kapcsán elrendelt rendkívüli állapot a jogállamiság „halála”, míg utóbbi károsítja azt. A harmadik esetkör a természeti katasztrófákhoz kapcsolódik. Ezek alapvetően nem veszélyesek a jogállamiságra - legalábbis kezdetben, míg a politikai elemek kisebb szerepet játszanak (Scheppele, 2020). Schmitt rendkívüli állapottal, különleges jogrenddel és az állami szuverenitással kapcsolatos tanainak elemzéséhez lásd még: Scheppele, 2004.

96 Langford et al., 2019, 228. o. 
HOLTER, S. (2010) Risikostyring i kraftbransjen. in proactima.no, 14. Oktober 2010 [Online]. Elérhető: https://docplayer.me/373087-Risikostyring-i-kraftbransjen.html (Letöltve: 2020. szeptember 10.)

Jovičić, S. (2020) 'COVID-19 Restrictions on Human Rights in the Light of the Case-law of the European Court of Human Rights', ERA Forum, 21(4), 545-560. o.

Justis- og beredskapsdepartementet (2014) Norges Grunnlov. Utforsk ord, uttrykk, begreper og historiske versjoner av Norges Grunnlov fra 1814 til 2014. in Lovdata, 25 Mai 2014 [Online]. Elérhető: https://grunnloven.lovdata.no/ (Letöltve: 2020. november 9.)

KHAKEE, A. (2009) Securing Democracy? A Comparative Analysis of Emergency Powersin Europe (Geneva Centre for the Democratic Control of Armed Forces Policy Paper - No. 30) [Online]. Elérhetô: www.files.ethz.ch/isn/99550/PP30_Anna_Khakee_Emergency_Powers.pdf (Letöltve: 2020. december 15.)

Krunke, H., Thorarensen, B. (szerk.) (2018) The Nordic Constitutions. A Comparative and Contextual Study. 1. kiadás. Bloomsbury: Hart Publishing

LANGFord, M., Berge, B. K. (2019) 'Norway's Constitution in a Comparative Perspective', Oslo Law Review, 6(3), 198-228. o.

LÆgreid, P., RYkKJA, L. H. (2014) 'Coordinating for Crisis Management in Norway after the Terrorist Attack in 2011' in Lægreid, P., Sarapuu, K., Rykkja, L. H., Randma-Liiv, T. (szerk.) Organizing for Coordination in the Public Sector. Public Sector Organizations. 1. kiadás. London: Palgrave Macmillan

MagnuSSEN, A.-M. (2005) Domstolskapt rett. En institusjonell analyse av utviklingen av regelen om ulovfestet objektivt ansvar fra 1866-2003. 1. kiadás. Bergen: Universitetet Bergen

Mehring, R. (2020a) Carl Schmitt und die Pandemie. Teil II. [Online]. Elérhetó: https:// verfassungsblog.de/carl-schmitt-und-die-pandemie-teil-ii/ (Letöltve:2020. november 11.)

Mehring, R. (2020b) Carl Schmitt und die Pandemie. Teil I. [Online]. Elérhetô: https:// verfassungsblog.de/carl-schmitt-und-die-pandemie-teil-i/ (Letöltve: 2020 . november 11.)

MiCHALSEN, D. (szerk.) (2013) Unntakstilstand og forfatning. Brudd og kontinuitet i konstitusjonell rett. 1. kiadás. Oslo: Pax Forlag

MIDTGAARD, A. K. (2018) Risikoanalyser innen safety og security på samfunnsnivå-hva er likt og hva er ulikt? [Online]. Elérhető: https://tinyurl.com/w4jtaaw3 (Letöltve: 2020. november 1.)

Nicolaisen, C., Wetlesen, M., Brøndmo, P. (2020) Covid-19 Legislation: Norway [Online]. Elérhetô: www.coronavirus-legislation.com/home/norway (Letöltve: 2020. november 11.) NOU (Norges offentlige utredninger) (2019) Når krisen inntreffer. Oslo: Departementenes sikkerhets- og serviceorganisasjon

NSM (Nasjonal sikkerhetsmyndighet) (2020) Risiko 2020. Sandvika: Nasjonal sikkerhetsmyndighet

MOD (Norwegian Ministry of Defence), MOJ (Norwegian Ministry of Justice and Public Security) (2018) Support and Cooperation. A Description of the Total Defence in Norway. Oslo: MOD, MOJ 
Múlt-Kor (2018) Megelőzték a németek a szövetségeseket Norvégia megszállásával [Online]. Elérhető: https://mult-kor.hu/megeloztek-a-nemetek-a-szvetsegeseket-norvegia-megszallasaval20181004?pIdx=1 (Letöltve: 2020. november 11.)

Múlt-Kor(2019)Ahatárértékszázezerszeresévelsugározaz1989-benelsüllyedtszovjetatom-tengeralattjáró [Online]. Elérhető: https://mult-kor.hu/a-hatarertek-szazezerszeresevel-sugaroz-az-1989ben-elsullyedt-szovjet-atom-tengeralattjaro-20190710 (Letöltve: 2020. november 19.)

SCHEPPELE, K. L. (2004) 'Law in a Time of Emergency: States of Exception and the Temptations of 9/11', University of Pennsylvania Journal of Constitutional Law, 6(5), 1001-1083. o.

SCHEPPELE, K. L. (2020) Underreaction in a Time of Emergency: America as a Nearly Failed State [Online]. Elérhetó: https://verfassungsblog.de/underreaction-in-a-time-of-emergencyamerica-as-a-nearly-failed-state/ (Letöltve: 2020 . november 11.)

SMET, S. (2010) 'Freedom of Expression and the Right to Reputation: Human Rights in Conflict', American University International Law Review, 26(1), 183-236. o.

OJANEN, M. M.-T. (2018) 'Human Rights in Nordic Constitutions and the Impact of International Obligations' in Krunke, H., Thorarensen, B. (szerk.) The Nordic Constitutions: A Comparative and Contextual Study. 1. kiadás. London: Hart Publishing

PST (Politiets sikkerhetstjeneste) (2020) Nasjonal trusselvurdering 2020 [Online]. Elérhető: www.pst.no/alle-artikler/trusselvurderinger/nasjonal-trusselvurdering-2020/ (Letöltve: 2020. december 2.)

RADJENOviC, A., ECKERT., G. (2020) Upholding Human Rightsin Europe during the Pandemic' (European Parliamentary Research Service) [Online]. Elérhető: www.europarl.europa.eu/RegData/etudes/ BRIE/2020/652085/EPRS_BRI(2020)652085_EN.pdf (Letöltve: 2020. november 11.)

ReusCH, C. (2020) The Norwegian Parliament Adopts New Corona Act [Online]. Elérhetô: https:// svw.no/artikler/the-norwegian-parliament-adopts-new-corona-act (Letöltve: 2020. december 1.)

SzENTGÁLI-Tóth, B. (2014) Európa legrégibb hatályos alkotmánya: Norvégia [Online]. Elérhetô: https://arsboni.hu/europa-legregibb-hatalyos-alkotmanya-norvegia/ (Letöltve: 2020. november 9.)

TÁLAs, P., CsíkI, T. (2011) 'Az oslói/utøyai merényletről', ZMNE Stratégiai Védelmi Kutató Központ Elemzések, 2011/8.

TøNDER, B. (2014) 'The Control of the Legislative and the Executive Power by Norwegian Courts', Panstwo i Prawo, 69(5), 74-84. o.

Universitetet i Oslo (2020) Norges historie, fra steinalderen til i dag. Fortalt av fagfolk [Online]. Elérhető: www.norgeshistorie.no/ (Letöltve: 2020. november 9.)

Vik, H. H., Jensen, S. L. B., Lindkvist, L., Strang, J. (2018) 'Histories of Human Rights in the Nordic Countries', Nordic Journal of Human Rights, 36(3), 189-201. o.

WIND, M., FøLLESDAL, A. (2009) 'Introduction - Nordic Reluctance Towards Judicial Review Under Siege', Nordisk Tidsskrift for Menneskerettigheter, 27(2), 131-141. o.

WJP (2020) World Justice Project Rule of Law Index 2020. Washington: WJP 